\title{
Faktor-Faktor Yang Berhubungan Dengan Gangguan Pendegaran Pada Pekerja Bengkel Las Di Kelurahan Suka Karya Kota Jambi
}

\author{
Syafwandi Akbar, Sugiarto, Melda Yenni \\ 'Sekolah Tinggi Ilmu Kesehatan Harapa Ibu Jambi, Jambi \\ ${ }^{1}$ syafwandi.akbar@yahoo.com; ${ }^{2}$ mas sugik32@yahoo.com
}

\begin{abstract}
Abstrak
Bengkel las merupakan salah satu tempat kerja yang berpotensi menimbulkan gangguan pendengaran. Gangguan pendengaran tersebut disebabkan karena intensitas kebisingan yang tinggi pada saat pekerja memotong besi saat bekerja. Jika pekerja berada pada intensitas yang melampau NAB $(>85 \mathrm{~dB})$ maka akan menyebabkan gangguan pendengaran. Penelitian bertujuan mengetahui mengetahui faktor yang berhubungan dengan gangguan fungsi pendengaran pada pekerja bengkel las di Kelurahan Suka Karya. Desain penelitian adalah cros sectional. Sampel penelitian adalah pekerja bengkel las di Kelurahan Suka Karya. Teknik pengambilan sampel menggunakan teknik purposive sanpling. Penelitian dilakukan bulan Mei - Juni 2020. Analisa data menggunakan uji chi-square dan uji khrushall wallis. Sebanyak 36,2\% responden mengalami tuli konduktif, 34,0\% responden mengalami tuli sensorineural, sebesar $29,8 \%$ responden tidak mengalami gangguan pendengaran. Rata-rata intensitas kebisingan sebesar 81,49 $\mathrm{dB}$, sebanyak 78,7\% responden memiliki masa kerja $>5$ tahun dan sebanyak 93,6\% responden tidak menggunakan alat pelindung telingga. Hasil analisis bivariat menunjukkan bahwa ada hubungan antara intensitas kebisingan dengan gangguan pendengaran pada pekerja bengkel las di Keluarahan Suka Karya Tahun $2020(\mathrm{p}=0,001)$. Tidak ada hubungan antara masa kerja $(\mathrm{p}=0,150)$ dan penggunaan alat pelindung telingga $(\mathrm{p}=0,375)$ dengan gangguan pendengaran pada pekerja bengkel las di Keluarahan Suka Karya Tahun 2020. Diharapkan pekerja selalu menggunakan alat pelindung telingga ketika bekerja. Bagi pemilik bengkel las untuk menyediakan alat pelindung telingga yang dapat dipakai oleh pekerja.
\end{abstract}

Kata Kunci : Gangguan Fungsi Pendengaran, Intensitas Kebisingan, Masa Kerja, Alat Pelindung Telingga

Abstract
Welding workshop is one of the workplaces that has the potential to cause hearing
loss. The hearing loss is caused by the high intensity of noise when workers cut
metal while working. If workers are at an intensity that exceeds TLV (> 85dB) it
will cause hearing loss. This study aims to determine the factors associated with
hearing loss in welding workshop workers in Suka Karya Village. The research
design was cross sectional. The research sample was a welding workshop worker
in Suka Karya Village. The sampling technique used the purposive sanpling
technique. The study was conducted in May - June 2020. Data analysis used the
chi-square test and the Khrushall Wallis test. A total of 36.2\% of respondents
experienced conductive deafness, $34.0 \%$ of respondents experienced


sensorineural deafness, and 29.8\% of respondents had no hearing loss. The average noise intensity is $81.49 \mathrm{~dB}$, as many as $78.7 \%$ of respondents have a service life of 5 years and as many as $93.6 \%$ of respondents do not use ear protection equipment. The results of the bivariate analysis show that there is a relationship between noise intensity and hearing loss in welding workshop workers in the Suka Karya Family in 2020 (p-value =0.001). There is no relationship between work tenure ( $p$-value $=0.150)$ and the use of ear protection equipment ( $p$-value $=0.375$ ) with hearing loss in welding workshop workers in the Joyful Work Family in 2020. It is expected that workers always use ear protective equipment when working. For welding workshop owners to provide ear protection devices that can be worn by workers

Keywords: Hearing Impairment, Noise Intensity, Service Period, Ear Protection Equipment

\section{PENDAHULUAN}

Seseorang yang bekerja dengan intensitas bising yang tinggi maka akan berisiko mengalami gangguan pendengaran. Lingkungan yang bising dan tanpa disertai penggunaan alat pelindung diri (APD) telingga maka dapat memperparah gangguan pendengaran (Suma'mur, 2014). Penggunaan APD telingga dapat mengurangi intensitas kebisingan sehingga seseorang yang bekerja di lingkungan yang bising harus menggunakan APD telingga sehingga dapat mencegah terjadinya gangguan pendengaran. Jenis APD telingga yang digunakan pekerja untuk mengurangi intensitas kebisingan adalah penutup telingga (ear muff) dan sumbat telingga (ear plug) (Permenakertrans No 8, 2010).

Salah satu usaha industri yang bekembang pesat saat ini adalah pengelasan (welding). Pengelasan merupakan suatu cara untuk menyambung benda padat dengan jalan mencairkannya melalui pemanasan. Teknologi dan peralatan kerja yang modern pada industri seperti mesin mesin atau alat-alat sekarang semakin banyak dan berkembang, mulai dari jenis hingga jumlahnya. Penggunaan mesin dan peralatan kerja tersebut akan menimbulkan kebisingan yang menyebabkan gangguan komunikasi, konsentrasi serta kenikmatan kerja hingga pada cacat kehilangan daya dengan yang menetap (Suma'mur, 2014).

Bengkel las merupakan salah satu tempat usaha dimana kegiatan produksinya dapat menimbulkan kebisingan sehingga pekerja yang bekerja dapat berisiko mengalami gangguan pendengaran. Kebisingan di bengkel las dapat terjadi karena salah satu kegiatannya adalah pemotongan besi. Jika pekerja 
tersebut tidak menggunakan APD telingga maka akan memperparah gangguan pendengaran. Kegiatan produksi begkel las di Kecamatan Suka Karya antara lain pembuatan permaianan untuk TK, peranca bangunan, tiang teratak, tenda cafe, payung taman, jerjak, pagar, dan pintu besi. Alat-alat yang di gunakan yang menjadi sumber kebisingan yaitu gerida tangan (hand grinding), gerinda duduk, kompresor angin, palu. Besi yang digunakan untuk produksi yaitu besi pipa dan besi padat. Ukuran dari besi tersebut ada berbagai ukuran, dengan panjang awal 5 meter.

Hasil obervasi peneliti pada tanggal 24 Maret 2020 diketahui bahwa proses yang ada dibengkel las ada beberapa tahap yang dilakukan untuk menghasilkan barang. Besi yang masih utuh akan dipotong sesuai dengan ukuran yang dibutuhkan dengan gerinda potong. Bekas potongan tersebut dapat menyebabkan celaka/luka bagi yang menyentuhnya, sehingga ujungnya di haluskan dengan gerinda tangan. Setelah itu, masuk pada proses pengelasan sesuai dengan apa yang ingin di produksi dengan menggunakan mesin las. Selanjutnya proses pengecatan yang dilakukan dengan dua metode yaitu manual atau dengan kompresor angin. Pada proses pengerjaan tersebut maka terciptalah kebisingan di bengkel las yang langsung terpapar terhadap para pekerja.

Jenis kebisingan yang ada dibengkel las tersebut termasuk jenis kebisingan kontinyu atau kebisingan tetap. Kondisi bising di area bengkel cukup mengganggu bagi pekerja yang berada di dalam bengkel bahkan dapat berdampak pada kesehatannya. Gangguan pendengaran yang dialami oleh pekerja yaitu menurunya daya dengar, hal tersebut terlihat pekerja bersuara keras ketika berbicara dengan pekerja lainnya, telingga berdengung, rasa nyeri dalam telingga.

Hasil pengukuran kebisingan di 3 (tiga) Bengkel Las yang ada di Kelurahan Suka Karya diperoleh hasil bahwa nilai ambang kebisingan di bengkel tersebut adalah $84,1 \mathrm{~dB}, 85,5 \mathrm{~dB}$, dan 98,4 dB. Sedangkan pekerja di bengkel tersebut bekerja dimulai dari pukul 09.00-18.00 WIB di hari Senin-Sabtu. Ada 12 Pekerja di 3 bengkel las tersebut, ada 8 orang pekerja tidak menggnakan APT, 2 orang menggunakan kapas untuk menutupi telingga dan 2 orang menggunakan ear plug dalam bekerja. 
Penelitian ini ingin melihat faktor yang berhubungan dengan gangguan pendengaran pada pekerja bengkel las di Kelurahan Suka Karya Tahun 2020

\section{METODE PENELITIAN}

Penelitian merupakan penelitian kuantitatif menggunakan desain cross sectional. Penelitian dilakukan di Bengkel Las yang ada di Keluahan Suka Karya pada bulan Mei s/d Juni 2020. Sampel penelitian adalah pekerja bengkel las di Kelurahan Suka Karya sebanyak 50 orang. Sampel diambil secara purposive sampling. Instrumen penelitian antara lain sound level meter, garpu tala dan lembar observasi. Metode pengumpulan data dengan pengukuran gangguan pendengaran menggunakan garpu tala, pengukuran kebisingan menggunakan sound level meter dan observasi untuk melihat penggunaan APD. Data dianalsis dengan uji chi-square dan uji khrushall wallis.

\section{HASIL DAN PEMBAHASAN}

Hasil analisis univariat diperoleh $36,2 \%$ responden mengalami tuli konduktif, $34,0 \%$ responden mengalami tuli sensorineural, sebesar $29,8 \%$ responden tidak mengalami gangguan pendengaran. Rata-rata intensitas kebisingan sebesar 81,49 $\mathrm{dB}$, sebanyak 78,7\% responden memiliki masa kerja $>5$ tahun dan 93,6\% responden tidak menggunakan APD (Tabel 1)

Hasil analisis bivariat diperoleh ada hubungan antara intensitas kebisingan dengan gangguan pendengaran pada pekerja bengkel las di Keluarahan Suka Karya Tahun 2020 (p-value $=0,001)$ (Tabel 2). Tidak ada hubungan antara masa kerja $(p$-value $=150)$ dan penggunaan alat pelindung telingga $(p$-value $=0,375)$ dengan gangguan pendengaran pada pekerja bengkel las di Keluarahan Suka Karya Tahun 2020 (Tabel 3).

Tabel 1. Distribusi gangguan pendengaran, masa kerja, penggunaan APT dan intensitas kebisingan pada pekerja bengkel las di Kelurahan Suka Karya

\begin{tabular}{lcc}
\hline \multicolumn{1}{c}{ Variabel } & Jumlah & $\%$ \\
\hline $\begin{array}{l}\text { Gangguan Pendengaran } \\
\text { Tuli Sensorineural }\end{array}$ & 14 & 29,8
\end{tabular}




\begin{tabular}{lcc} 
Tuli Konduktif & 17 & 36,2 \\
Normal & 16 & 34,0 \\
\hline Masa Kerja & 37 & 78,7 \\
Lama & 10 & 21,3 \\
Baru & & \\
\hline Penggunaan APT & 44 & 93,6 \\
Tidak Menggunakan & 3 & 6,4 \\
Menggunakan & & \\
\hline Intensitas Kebisingan & 81,49 & \\
Mean & 6,41 & \\
SD & 68,1 & \\
Minimal & 90,1 & \\
Maksimal &
\end{tabular}

Tabel 2 Hubungan Intensitas Kebisingan dengan Gangguan Pendengaran Pada Pekerja Bengkel Las di Kelurahan Suka Karya Kota Jambi

\begin{tabular}{lcccc}
\hline \multicolumn{1}{c}{ Variabel } & N & Mean & SD & P-value \\
\hline Gangguan Pendengaran & & & & \\
Tuli Sensorineural & 14 & 84,90 & 5,13 & 0,001 \\
Tuli Konduktif & 17 & 83,29 & 5,12 & \\
Normal & 16 & 81,49 & 5,99 & \\
\hline
\end{tabular}

Tabel 3 Hubungan Masa Kerja dan Penggunaan APT dengan Gangguan Pendengaran Pada Pekerja Bengkel Las di Kelurahan Suka Karya Kota Jambi

\begin{tabular}{|c|c|c|c|c|c|c|c|c|c|c|}
\hline \multirow{3}{*}{ No } & \multirow{3}{*}{ Variabel } & \multicolumn{6}{|c|}{ Gangguan Pendengaran } & \multicolumn{2}{|c|}{ Total } & \multirow{3}{*}{$\begin{array}{c}\mathrm{p}- \\
\text { value }\end{array}$} \\
\hline & & \multicolumn{2}{|c|}{$\begin{array}{c}\text { Tuli } \\
\text { Sensorineural }\end{array}$} & \multicolumn{2}{|c|}{$\begin{array}{c}\text { Tuli } \\
\text { Konduktif }\end{array}$} & \multicolumn{2}{|c|}{ Normal } & \multirow[t]{2}{*}{$\mathrm{n}$} & \multirow[t]{2}{*}{$\%$} & \\
\hline & & $\mathrm{n}$ & $\%$ & $\mathrm{n}$ & $\%$ & $\mathrm{n}$ & $\%$ & & & \\
\hline \multicolumn{11}{|c|}{ Masa Kerja } \\
\hline 1. & Lama & 10 & 27,0 & 16 & 43,2 & 11 & 29,7 & 37 & 100 & \multirow{2}{*}{0,150} \\
\hline & Baru & 4 & 40,0 & 1 & 10,0 & 5 & 50,0 & 10 & 100 & \\
\hline \multicolumn{11}{|c|}{ Penggunaan APT } \\
\hline 1 & $\begin{array}{l}\text { Tidak } \\
\text { menggunakan }\end{array}$ & 14 & 31,8 & 16 & 36,4 & 14 & 31,8 & 44 & 100 & \multirow[t]{2}{*}{0,375} \\
\hline 2 & Menggunakan & 0 & 0,00 & 1 & 33,3 & 2 & 66,7 & 3 & 100 & \\
\hline
\end{tabular}

Hasil uji statistik diperoleh nilai $\mathrm{p}=0,001(\mathrm{p}<0,05)$, maka dapat disimpulkan bahwa intensitas kebisingan memiliki hubungan yang bemakna dengan gangguan pendengaran. Hal tersebut berarti semakin tinggi pajanan bising maka semakin berisiko mengalami gangguan pendengaran. Penelitian Ibrahim (2014) 
menunjukkan hal yang sama dimana intensitas kebisingan memiliki hubungan yang bermakna dengan gangguan pendengaran $(p=0,000)$. Penelitian Urai Yuniarsih, Sunarsieh \& Salbiah (2016) di PT Sintang Raya juga menunjukkan hal yang sama dimana gangguan pendengaran pada pekerja di PT Sintang Raya berhubungan dengan intensitas kebisingan $(p=0,004)$.

Intensitas kebisingan merupakan faktor risiko gangguan pendengaran. Banyaknya pekerjaan yang mengalami gangguan pendengaran disebabkan sering terpapar bising yang cukup tinggi yang dihasilkan dari mesin dan peralatanperalatan kerja (Suma'mur, 2014). Pengukuran intensitas bising yang dilakukan dalam penelitian ini adalah untuk mengukur seberapa besar bising yang diterima pekerja dengan menggunakan alat ukur aplikasi sound level meter. Hasil pengukuran dengan menggunakan sound level meter menunjukkan bahwa ratarata intensitas kebisingan pada responden sebesar 81,49 dB.

Ada hubungan antara kebisingan dengan gangguan pendengaran pada pekerja bengkel las di Kelurahan Suka Karya. Hal tersebut disebabkan responden bekerja berada sangat dekat dengan sumber bising dan berlangsung selama 8 jam. Kebisingan dari sumber-sumber ini tidak dapat dihindari oleh responden, karena aktivitas dan keberadaan mereka pada saat bekerja. Jika responden terpapar bising lebih dari $85 \mathrm{~dB}$ selama 8 jam per hari dapat menyebabkan kehilangan pendengaran permanen selama beberapa tahun paparan. Keluhan yang dirasakan oleh responden diantaranya mereka harus memperkeras suara, sering merasa pusing dan mual. Jika hal ini dibiarkan terus menerus dimana tingkat pajanan melebihi nilai ambang batas dapat menyebabkan tuli permanen pada responden.

Hasil penelitian menunjukkan bahwa tidak ada hubungan antara masa kerja dengan gangguan pendengaran pekerja bengkel las di Kelurahan Suka Karya dengan nilai $\mathrm{p}$-value $=0,150$. Tidak ada hubungan antara masa kerja dengan gangguan pendengaran disebabkan sebagian besar responden berusia 34 tahun. Usia tersebut masih kategori muda sehingga pekerja tersebut masih memiliki pendengaran yang baik.

Penelitian Urai Yuniarsih, Sunarsieh \& Salbiah (2016) di PT Sintang Raya diperoleh hasil yang sama dimana masa kerja bukan merupakan faktor risiko gangguan pendengaran pada pekerja di PT Sintang Raya $(p=0,629)$. Penelitian 
Rezky Putri Indrawati Abdullah, Sigit Dwi Purnomo \& Ida Putri Ihsani (2020) di PT Semen Tonasa menunjukkan hal yang sama jenis tuli pada pekerja PT Semen Tonasa tidak berhubungan dengan masa kerja $(p=0,291)$.

Hasil uji statistik diperoleh nilai $p=0,375(\mathrm{p}>0,05)$, maka dapat disimpulkan bahwa tidak ada hubungan antara APT dengan gangguan pendengaran pada pekerja bengkel las di Kelurahan Suka Karya Kota Jambi. Penelitian Dini Rahmawati (2015) di PT Dirgantara Indonesia (Persero) diperoleh hasil bahwa gangguan pendengaran pada pekerja tidak berhubungan dengan penggunaan APD. Penelitian Evy Yulia Arini, Onny Setiyani \& Budiyono (2005) di PT Kurnia Jati Utama Semarang menunjukkan gangguan pendengaran tidak berhubungan dengan penggunaan APD. Penelitian Pristi Rahayu \& Eram Tunggul Pawenang (2016) menunjukkan bahwa tidak ada hubungan antara penggunaan APT dengan gangguan pendengaran.

Hasil penelitian ini menunjukkan bahwa tidak ada hubungan antara penggunaan APT dengan gangguan pendengaran pada pekerja di bengkel las Kelurahan Suka Karya dikarenakan perusahaan tidak menyediakan APT sehingga pekerja tidak menggunakan APT saat bekerja. Sesuai dengan hasil analisis univariat diperoleh hasil sebanyak 93,6\% responden tidak menggunakan APT. Jika dilihat dari nilai persentasi tersebut menunjukkan bahwa data ini homogen sehingga mempengaruhi ada atau tidaknya hubungan antara penggunaan APT dengan gangguan pendengaran hasil penelitian ini.

\section{KESIMPULAN}

Berdasarkan hasil penelitian diketahui bahwa 36,2\% responden mengalami tuli konduktif, 34,0\% responden mengalami tuli sensorineural, sebesar 29,8\% responden tidak mengalami gangguan pendengaran. Rata-rata intensitas kebisingan sebesar $81,49 \mathrm{~dB}$, sebanyak $78,7 \%$ responden memiliki masa. Faktor yang berhubungan dengan gangguan pendengaran adalah intensitas kebisingan.

\section{SARAN}

Diharapkan kepada pekerja untuk selalu menggunakan APT ketika sedang bekerja, sehingga dapat mengurangi paparan bising. 


\section{DAFTAR PUSTAKA}

Abdullah, Rezky P I., Pramono, Sigit D \& Ihsani, Ida P. (2020). Hubungan Kebisingan dan Masa Kerja terhadap Jenis Ketulian dan Stress Pada Pekerja PT. Semen Tonasa. UMI Medical Journal. Vol 5(1)69-80

Arini, Evy Yulia., Setiyani, Onny \& Budiyono. (2005). Faktor-Faktor yang Berhubungan dengan Gangguan Pendengaran Tipe Sensorineural Tenaga Kerja Unit Produksi PT. Kurnia Jati Utama Semarang. J Kesehatan Lingkungan Indones. Vol 4(1)23-26

Ibrahim, Habsi. Basri, S. \& Hamzah, Z. 2014. Faktor-faktor yang Berhubungan dengan Keluhan Gangguan Pendengaran pada Tenaga Kerja Bagian Produksi PT. Japfa Comfeed Indonesia, Tbk. Unit Makassar Tahun 2014. Al-Sihah: Public Health Science Journal. Vol III, No. 2; 121-129

Rahayu, Pristi \& Pawenang, Eram Tunggul. (2016). Faktor yang Berhubungan dengan Gangguan Pendengaran pada Pekerja yang Terpapar Bising di Unit Spinning I PT. Sinar Pantja Djaja Semarang. Unnes Journal of Public Helath, Vol. 5(2)140-148

Rahmawati, Dini. (2015). Faktor-Faktor yang Berhubungan dengan Gangguan Pendengaran pada pekerja di Departemen Metal Forming dan Heat Treatment PT Dirgantara Indonesia (persero) Tahun 2015. Skripsi: Universitas Islam Negeri Syarif Hidayatullah

Saus GA. (2014). A strategic formulation to decrease the number of hearing impaired people in Indonesia. Dalam: Suzuki J, Kobayashi T, Koga K, penyunting Hearing impairment. Japan: Springer; 2014. hlm. 458-9

Suma'mur, 2014. Kesehatan Kerja Dalam Perspektif Hiperkes dan Keselamatan Kerja. Penerbit: Erlangga. Jakarta.

Tarwaka. 2014. Kesehatan dan Keselamatan Kerja : Manajemen dan Implementasi K3 di tempat Kerja. Surakarta: Harapan Press

Yuniarsih, Urai., Sunarsieh \& Salbiah. (2016). Hubungan Penggunaan APD Telingga dengan Gangguan Pendengaran pada Pekerja Pabrik di PT Sintang Raya Kabupaten Kubu Raya. Sanitarian, Vol 8(3)342-348 